New Zealand journal of industrial relations, 1988, 13, 213-235

\title{
ARTICLES
}

\section{Union compliance and incomes policy: The Australian Social Contract, 1983-87}

\author{
Julian Teicher*
}

Australia has a long experience of centralised wage-fixing through the federal and state systems of conciliation and arbitration, but until 1975 this machinery was not embedded in a more general incomes policy. Although this was undermined progressively and finally abandoned in 1981, a further incomes policy was introduced two years later. following the election of a federal Labour government. Overseas experiences indicates that the structural features of the union movement are important determinants of the success of an incomes policy. Australian experience since 1983, however, indicates that, despite large numbers of competing unions and a union peak council lacking formal control over affiliates, an incomes policy may be viable. This reasoning was supported by empirical evidence pertaining to the role of the Australian Council of Trade Unions in securing compliance from affiliated unions.

\section{Introduction}

Australia and New Zealand are usually given little attention in the incomes policy literature (Boston 1986, p.3). In the Australian case this is surprising, because the conciliation and arbitration systems constitute an institutional framework and processes conducive to the operation of an incomes policy (Phelps Brown, 1978, pp.73-83). In the Australian incomes policy literature, a pessimistic prognosis has usually rested on the union movement's lack of cohesion and, in particular, the destabilising consequences of strategically placed groups of workers achieving wage settlements in excess of the centrally determined norm (for example, Yerbury 1980, p.470 and Blandy and Creigh 1983, p.160).

The ensuing discussion challenges the pessimistic view; its main concern is with the capability and success of the Australian Council of Trade Unions (ACTU) in securing union compliance with the provisions of the Statement of Accord by the Australian Australia, 3168. 
Labour Party and the Australian Council of Trade Unions. It is stressed that compliance with the incomes policy does not result only from enforcement by the ACTU, but also reflects an assessment by unions and unionists of the net benefits of the Accord and its associated processes. The discussion proceeds on the basis that, despite differences in the economic, social and political circumstances of Australia and New Zealand, in the industrial relations sphere the commonalities are such that the experiences of one country may be instructive for the other.

\section{Background: incomes policy developments}

Economic conditions were already declining in 1972, when a federal Labour government was elected for the first time in 23 years. Both unemployment and inflation were increasing; the "money wage explosion" of 1973-75 was perhaps the central feature of this period with average weekly earnings increasing at an average annual rate of 19.9 percent and peaking at 28.4 percent, in 1974. Such was the deterioration that, in June 1974, the federal government issued a call for wage restraint, although in the 1973 national wage case it had argued that substantial wage increases could be awarded without inflationary consequences (Nieuwenhuysen 1986, p.70-1).

The implementation of wage controls was constrained by the Constitution, however, which prohibits federal governments from directly setting wages and preserves separate industrial jurisdictions at federal and state levels. Consequently, wage restraint could not be secured without the assistance of the Commission and its state counterparts. In addition, the demise of the penal sanctions in the Conciliation and Arbitration Act in 1969 , following a campaign of union opposition, meant that the restoration of a centralised wage-fixing system would require the co-operation of key unions and the ACTU.

Despite continuing reservations as to the viability of a centralised wage-fixing system, the Commission concluded in April 1975 that there was sufficient consensus between the major economic interest groups to warrant the trial adoption of a system of prima facie full wage indexation. The Commission's decision was conditional on the implementation of "supporting mechanisms" by the federal government. These included continuing support for the operation of the Prices Justification Tribunal, upholding the indexation guidelines in areas of public employment outside the Commission's jurisdiction and ensuring federal government policies did not conflict with the operation of the wage-fixing system (Plowman 1983, p.416). Thus came into being Australia's first voluntary incomes policy.

In November 1975, the federal government was removed from office by the Governor General and a conservative coalition was returned at the ensuing election. The incoming Liberal-National Country Party (L-NCP) government opposed wage indexation consistently and undermined the supporting mechanisms. Apparently influenced by the federal government, the Commission only rarely awarded full wage indexation and persisted with centralised wage-fixing, despite the government's hostility. In the circumstances, the state tribunals increasingly asserted their independence of the wagefixing principles and collective negotiations become more common. Finally, in July 1981 , the Commission terminated the wage indexation system as it became known. The trigger for its decision was a collectively bargained wage round and associated increased industrial disputation which led to real average weekly earnings rising at 3.2 percent in 1980/81 (Rimmer 1987, pp.100-1).

In the following months, the pattern of wage-fixing, in essence, became decentralised, although this was qualified by the state tribunals continuing to award across the board wage increases (Rimmer 1987, pp.103-4). With the conclusion of an agreement in the pacesetting metal industry and its ratification by the Commission in December 1981, the wage round became more structured. Following the Metal Industry Agreement, money 
wage increases of 17.6 percent were rapidly transmitted through the economy, notwithstanding the adoption of a non-accommodating monetary policy by the government. Confronted by rapidly rising real wages and increasing inflation and unemployment, the government responded pragmatically. In December 1982, a 12-month wages freeze was legislated for federal government employees and, with the co-operation of the tribunals and state governments, a 6-month wages freeze was applied to most other employees. Predictably, this provoked protest strikes, notably in the strategic oil and transport industries. Against this backdrop of increasing economic and industrial relations instability, the government called an early election. At the polls a month later Labour was returned; an important element in its victory was the Accord or social contract with the unions. Although it was ratified by ACTU affiliates at a hastily-convened conference immediately prior to the election, it was more in the character of an agreement negotiated between the Labour Party and the ACTU over the preceding four years.

The Accord was a detailed and wide-ranging document, although this discussion emphasises the wages provisions. It committed an incoming Labour government to supporting restoration of a centralised wage-fixing system, regular indexation of award and overaward payments to maintain their real value and periodic wage adjustments to reflect labour's contribution to rising national productivity. In return for these and other commitments relating to prices, non-wage incomes, taxation, government expenditure and tripartite consultation on economic policy, the ACTU accepted that "in a period of economic crisis as now applying", partial wage indexation could apply and, except in "special and extraordinary circumstances", there would be no extra claims (Statement of Accord 1983, p.10).

A key feature of the Accord was that its provisions were not endorsed by any employer organisations. The newly-elected Labour government attempted to rectify this by convening the National Economic Summit Conference. Tripartite support for its wages provisions was clearly required in order to convince the Commission to implement a centralised system. In this respect, the Summit was a success, securing an unprecedented tripartite endorsement of the logic, but not the details of an incomes policy (National Economic Summit 1983, p.8).

Accordingly, in September 1983, the Commission endorsed the resumption of a centralised wage-fixing system based on prima facie real wage maintenance at half-yearly intervals, deferred consideration of union claims for a wage adjustment based on national productivity movements and provided for additional increases in a limited number of exceptional circumstances. A novel feature of the principles was that the Commission attempted to internalise enforcement; receipt of increases was made conditional on all unions which were parties to an award undertaking not to pursue any extra claims, except in accordance with the principles. As explained below, individual responsibility was supplemented with an ACTU commitment that it would attempt to ensure that affiliates complied with the guidelines. In this way, the principles reflected the reality that, notwithstanding the quasi-judicial nature of the tribunals, the application of legal sanctions does not provide a sufficient basis for wage regulation.

Table 1 presents data linking movements in the consumer price index with compensating wage adjustments awarded by the Commission over the period ending in December 1986; at this time wage indexation ceased but centralised adjustments continued. The first national wage decision, in September 1983, awarded full wage indexation in relation to the first two quarters of the year. Without this gesture unions were unlikely to have given more than token adherence to the wage-fixing principles and, critically, the ACTU would not have jeopardised its credibility with affiliates by attempting to enforce compliance. 
Table 1: Movements in the Consumer Price Index and National Wage Case Decisions, Australia, 1983 - 1986 (percentage changes)

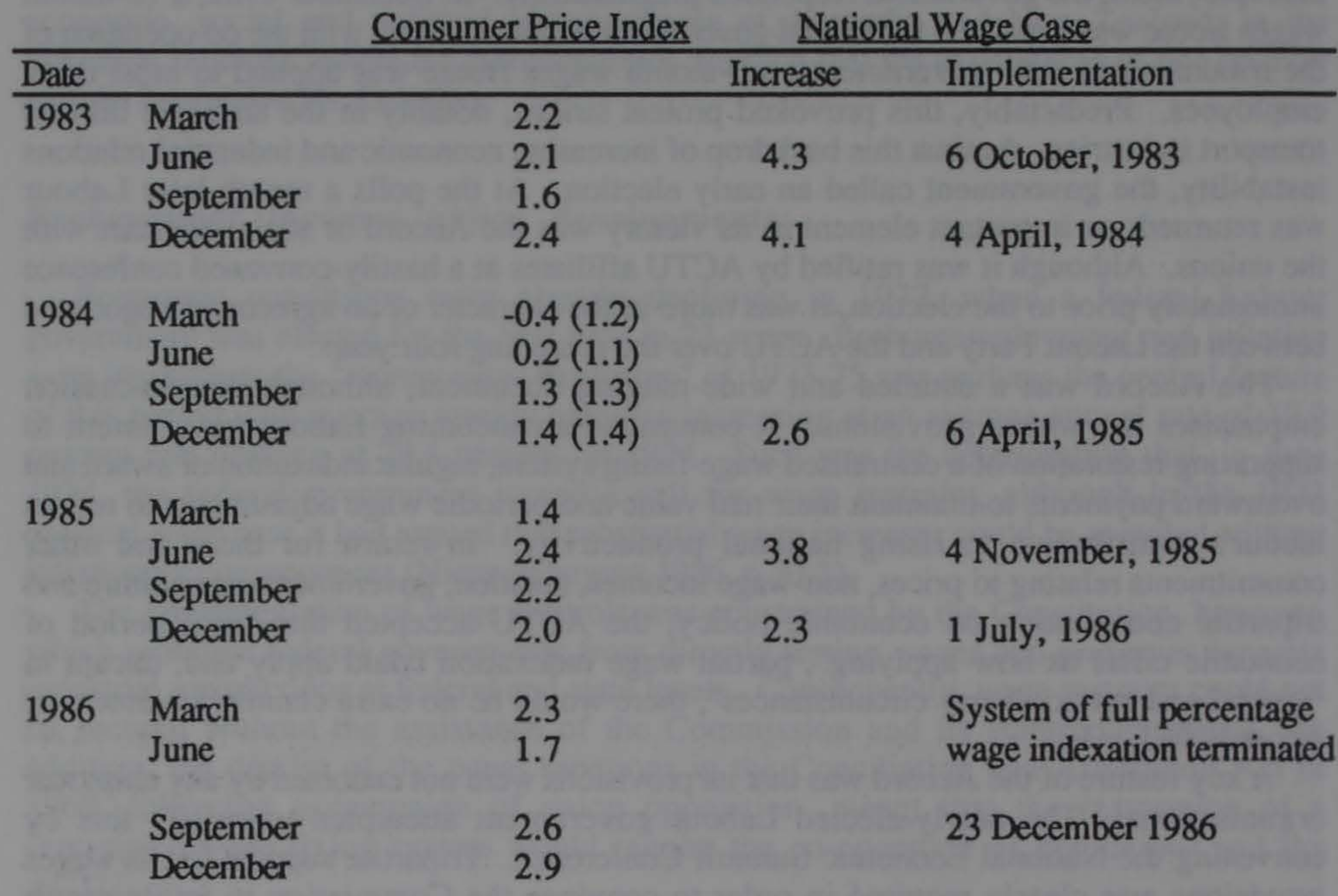

Note: Bracketed figures refer to CPI adjusted to exclude the effect of hospital and medical charges being deleted from the regimen.

Source: Kenyon (1986, p.137 and p.145), and ACAC (1986b, p. 57) .

\section{Unions and incomes policies}

The success of incomes policies depends upon the co-operation of the major economic interest groups, especially unions. In exchange, the interest groups can secure a wide range of benefits, both tangible and intangible. A central determinant of the viability of an incomes policy is the control which union confederations exert over their affiliates. Following Headey's (1970, p.412) pioneering study, this is often formulated in terms of the degree of centralization of the labour movement. For the 13 countries examined, Headey derived a "rough index" of centralization by classifying union confederations in terms of power to intervene in any of the stages of the collective bargaining process, percentage of strike funds controlled, and control over resources as measured by staff per thousand members and levels of affiliation fees. Despite reservations about its crudity, the index confirmed the importance of centralization in those countries where an incomes policy had operated for a period of at least 10 years (Headey 1970, pp.431-3). Also important to incomes policy viability in the period examined, 1947-69, was the election of governments sympathetic to the union movement and the occurrence of wage determination primarily at the national level, the latter being a prerequisite for effective union confederation intervention (Headey 1970, pp.416-23).

Subsequent research has tended to consider incomes policy within the context of an ongoing debate over corporatism and the class interests which are served by such 
arrangements. Overwhelmingly, this research has focused on the relationship between trade unions and the state (Wright and Apple 1980, p.453 and Regini 1984, p.127) and consideration of the union-centred issues has been largely derivative. Nonetheless, important insights into the issue of union compliance have been gained.

A central issue is to determine how unions "create a passive willingness on the part of their members to follow union directives and decisions, this being a precondition for the union's intermediary function" (Muller-Jentsch, 1985, p.23). Two groups of factors are identified, those based on the organisational structure and membership and the traditions and political orientations of the unions.

In the first category are restrictions placed on membership participation in the decisionmaking process and the extent to which specific groups have the opportunity to influence particular policies. Typically, command over resources and decision making tends to be centralised leaving members little scope to exert influence on important areas, particularly wages policy. These tendencies are often partly concealed by separating decision-making and participative processes. Of greater importance for Muller-Jentsch $(1985$, p.24) is membership composition; the larger and more cohesive a specific group, the greater its capacity to obstruct the implementation of a policy regardless of its representation on decision making bodies. Quite simply, unions rely on unpaid officials and the small minority of activists to implement policies and not to undertake activities in conflict with union policies.

In the second category is competition among leadership factions over ideological and policy issues and the influence exerted by the traditions of the union. For example, a union which owes its past successes primarily to opportunistic militancy is more likely to resort to industrial action than one with a history dominated by orderly industrial relations processes. Likewise, a union with a history of "going into battle" for specific interests within a heterogeneous membership is predicted to continue in that fashion. Also, the existence and nature of a union's political affiliations will influence its willingness to support the policies of the party in government (Muller-Jentsch, 1985, p.25-6). Presumably, that willingness will also be influenced by the organisational and membership structure of the union, but, in Muller-Jentsch's exposition, politicotraditional factors appear to exert an independent force, regardless of the organisational structure and decision making processes of the union.

Goldthorpe $(1984$, p.326) is seemingly more confident of the prospects for harmonising sectional and broader union movement or working class interests. Emphasis is placed on the specific benefits of an incomes policy in securing compliance rather than the structural features of the union movement. Using the examples of Austria, Sweden and Norway, Goldthorpe suggests stable corporatist bargaining usually is associated with union movement centralization and union leaders advocating a class position on political and economic issues and seeking to suppress "interests of a more sectional and shorterterm kind" (Goldthorpe 1984, p.329).

Closely allied to Goldthorpe's view is a line of reasoning associated with writers such as Olson (1982), Lange (1984) and Scharpf (1984). They reject the argument that incomes policy will be undermined by the free-riding behaviour of rational individuals, instead positing that:

If union organisation is concentrated with a limited number of "encompassing" industrial unions, and if collective bargaining is centralized at the national level, the unions will tend to consider the macroeconomic consequences of wage settlements out of rational self-interest (Scharpf 1984, p.275).

A related issue is the purported linkage between incomes policies, a low and declining incidence of strikes and superior economic performance. It suggests unions, but not necessarily their members, may have traded off disputation and wage increases for other 
desired outcomes, like reduced unemployment. A comprehensive examination of this linkage has been undertaken by Cameron (1984) and Schott (1984 and 1985). Over the period 1965-82, of 17 advanced capitalist nations, only in Japan, Austria, Norway and Sweden were increases in unemployment less than one percent and only in Japan, Austria, Germany, Switzerland and the Netherlands was the average annual rate of prices increase less than 3 percent. Working days lost through industrial disputes also were strongly correlated with the rate of change of nominal earnings and unemployment rates (Cameron 1984, pp.154-6). On the basis of this and other information, it was concluded that:

the simultaneous occurrence of price stability and full employment in some nations, and inflation and unemployment in others, reflects a complex causal relationship between the two, in which the relative quiescence or economic militancy of labour plays a critical intermediary role (Cameron 1984, p.157).

Further investigation revealed $(1984$, p.161) that low levels of strike activity and superior economic outcomes were achieved by countries with frequent leftist govemments, but the significance of this was attenuated by the existence of a series of notable exceptions. Hence, Britain and Denmark had higher unemployment rates than expected, while unemployment rates in Japan and Switzerland were low despite the absence of leftist governments. This prompted an investigation of whether the frequency of leftist governments was a surrogate for the power of organised labour. For that purpose, an index of union movement power was derived from the union density, number of union confederations and incidence of union affiliation, capacity of the union confederation to intervene in any of the stages of collective bargaining, scope of collective bargaining and the existence of employee participation schemes (Cameron 1984, pp.164-5). The resultant correlation between the organisational power of the union movement and leftist control of government was $r=+.79$, suggesting that the viability of incomes policy is connected with the organisational structure of the union movement (Cameron 1984, p.168) - a finding remarkably similar to that of Headey (1970) and Schmitter (1981, in Cameron 1984, p.168). These results, however, are of little assistance in explaining the exceptional cases, particularly labour quiescence in Germany, Japan and Switzerland despite their low scores for union movement power. Another apparent paradox is the decline in industrial militancy following the institution of corporatist arrangements in Britain and Italy in the early 1970's.

Of the weak corporatist nations, Britain and Italy are cases in which incomes policies have been attempted for limited periods. These experiences were instructive in two ways. First, they illustrate that viable incomes policies may be established, despite the absence of the structural and institutional conditions usually viewed as a sufficient for such arrangements. Hence, Italy provides a demonstration of the ways in which unions can avoid crises of representation. The absence of a single encompassing union confederation was accommodated by a "unitary pact" to avoid competition. Competition from autonomous unions was minimised by "using their political resources to force Parliament and government to grant them some degree of privileged recognition" and by launching an ideological offensive attacking the autonomous unions for their pursuit of sectional self interest. Union leaders participated in plant level negotiations, thereby limiting the scope for workers councils to articulate rank and file dissent (Regini 1984, pp.133-4).

Second, the essential condition for unions embracing an incomes policy is a widespread view among unionists that the net benefits are positive, so the eventual failure of an incomes policy may be attributable not to the absence of the structural and institutional conditions discussed above, but to non-realisation of the expected ratio of benefits to costs (Regini 1984, p.133). In both Britain and Italy, in the early 1970's, the net benefits of incomes policy appeared positive, but in the former case they changed and in the latter, could not be realised. 
Conversely, it is evident that the structural features of the union movement are no guarantee of the viability of an incomes policy. This point has been amply demonstrated by Fulcher (1987) in relation to the development of corporatist arrangements in Sweden. He concludes:

the key to understanding the radicalism of 1970 s Sweden is the idea of the contradictions of corporatism. The basic problem of corporatism is that it is an attempt to control powerful organisations through cooperation.....Control through cooperation is difficult either because control is subverted by the interest organisation, which seeks to bend policies in its favour, or because, if control is successful, the leadership of the organisation becomes alienated from its base (Fulcher 1987, p.248).

Hence, it was not until the 1960 s that wages policy became the vehicle for income redistribution toward the lower paid and was accorded priority over wage restraint. Likewise, until the Codetermination Law of 1976, the leadership of the Swedish Trade Unions Confederation (LO) opposed legislating for industrial democracy and, since 1906, had accepted employers' rights to hire and fire (Fulcher 1987, pp.241-6). In contrast to Higgins (1985), it is argued that the economic and social reforms of this period were forced upon the LO by an upsurge in rank and file militancy. The employers' response was unexpectedly militant: centralised wage negotiations became increasingly prolonged, employers reverted to using large scale lockouts and the Employers Federation (SAF) embarked on major propaganda campaigns against the government's reform legislation (Fulcher 1987, p.245).

Finally, a neglected aspect of the corporatist debates are the scattered observations, for example Lehmbruch $(1984$, p.67) and Schott $(1985$, p.17), which suggest that the character of workplace industrial relations is an important determinant of industrial disputation regardless of the existence of a national level corporatist arrangements. Accordingly, it is hypothesised that developed plant and enterprise level concertation is a major contributor to the superior economic performance of Germany, Japan and Austria, while the converse situation may help explain the economic malaise of countries like Italy and Britain. While consultative and participative bodies which are independent of unions, for example Works Councils, are best suited to workplace concertation, an accommodation can be reached with union negotiating bodies (Muller-Jentsch 1985, pp.7-9). Co-operative relations with the workforce can be fostered by the development of internal labour markets which gives the core workforce vested interests, like job security and promotions.

It is now possible to state the pre-conditions for union compliance with an incomes policy more broadly than in terms of the structural features of the union movement. These conditions can be summarised as follows:

1. Unions will agree to support incomes policies where, for whatever reason, the anticipated net benefits are superior or more assured than directly negotiating with employers. Relevant considerations could include the risks of fully utilising union bargaining power in a situation of economic crisis, organisational weakness of unions or the presence of a politically sympathetic government willing to make concessions to unions and unionists.

2. Depending on the character of the particular national union movement, it will be necessary to combat the de-stabilising influence on incomes policy of sectional interests. This will be facilitated where the organisational structure of the union movement and the level of negotiations are more highly centralised.

3. Where for any reason the expected ratio of costs and benefits shifts unfavourably for labour, unions will confront an incipient crisis of representation. The significance 
of that threat depends on the organisational resources available to individual unions and the pervasiveness of sectional, as opposed to class, allegiances among their members.

4. Enterprise and plant level industrial relations arrangements may depress levels of industrial disputation independently of the existence or operation of an incomes policy, as appears to be the case in both Austria and Japan.

\section{The ACTU and incomes policy}

A central issue for Australian incomes policy is the ACTU's capacity to secure union compliance. Thus, in establishing the new wage-fixing system, in 1983, the Commission supplemented the "no extra claims" undertaking of individual unions with an unprecedented ACTU undertaking to exercise "collective responsibility" for the industrial conduct of affiliates (ACAC 1983, pp.17-19). While the ACTU undertook to use all the resources at its disposal in an attempt to secure union compliance, reliance on enforcement is not the only factor in compliance. As is evident from the discussion, in the preceding section, union support for an incomes policy rests also on an assessment of the costs and benefits.

There has been considerable pessimism in the industrial relations literature as to the ACTU's capacity to secure union compliance. Thus, Dabscheck (1977, p.399), drawing upon Headey (1970), argues that the only factor explaining the ACTU's authority was its involvement in centralised wage-fixing, but even the operation of this factor is qualified. The ACTU's apparent success in restraining union wage demands after 1975 is attributed to a strategic decision that, in the depressed economic conditions, wage indexation would enable unions to secure higher wage levels than otherwise (Dabscheck 1977, p.398). More generally Dabscheck (1977, p.399) concludes:

Compulsory arbitration has developed calculative unions, a type of unionism which is prepared to instrumentally make use of "outside" or "external" bodies if this will enhance their prospects of realising their goals. The ACTU is such an "outside" body, but a body which has been created by the trade unions themselves.

This issue is taken up by Wooden (1985) in relation to the Accord. His broad conclusion that the dominance of "narrow interest coalitions" precludes viable ongoing corporatist arrangements rests on four groups of conditions not being met: cultural homogeneity of the population, openness of the economy, absence of competition between parties internal to the major economic interest groups and a high degree of centralization of such groups. Interestingly, Wooden's exposition concentrates on the union dimensions of the last-mentioned factor (Wooden 1985, pp.18-23) and is derived explicitly from Headey (1970) as updated and extended to Australia. Of the four constituents of Headey's index of union centralization, it is stated that "the only area in which the ACTU has been accorded any large measure of influence has been in the area of wage bargaining and certainly one objective of The [sic] Accord is to increase this degree of influence" (Wooden 1985, p.20).

Wooden's argument is supported by international comparisons indicating the ACTU's lack of control over union strike funds, the low level of affiliation fees remitted by unions and a fragmented union structure. Particular emphasis is on the organisational structure of Australian unions with large numbers of predominantly occupational unions. Competition between unions within a given workplace is said to ensure competition to preserve relativities and these claims will eventually radiate throughout the employed workforce (Wooden 1985, p.20). It is argued also that typically the "strong consensus" 
countries have small numbers of unions affiliated to a dominant union confederation, and, in Australia, the absence of that condition produces factionalism which is reflected in struggles over the composition of the ACTU Executive and the low level of funding approved by affiliates (Wooden 1985, p.20). Similar arguments have been advanced by others such as Dunkley (1984, p.381, and Dawkins and Blandy 1985, p.45).

In contrast to the views articulated by Wooden $(1985, \mathrm{p} .23)$ and others, it is argued below that the ACTU's capabilities have been underestimated and its changing character has not been considered. Further, Wooden's argument is derived apparently from an incorrect interpretation of Headey (1970) and is influenced excessively by the problem of free-riding behaviour. This leads him to overlook that compliance is not simply a function of the structural features of the union movement but turns also on an assessment of the net benefits of an incomes policy.

Dealing with the latter points first, Headey (1978, p.432) advanced centralization scores only as a "rough index". Especially important is the associated finding that, historically, affiliates tend to vest union confederations with authority to conduct incomes policy in times of economic crisis and over time "the continued exercise of this power is invested with a degree of legitimacy" (Headey 1970, p.412-4). In the ACTU's case, its involvement in centralised wage-fixing dates from the depression of the 1930's and, most recently, its legitimacy has been reinforced by the economic crises of the mid-1970s and early 1980s (Teicher 1987, pp.5-18). Further, reformulating Headey's influence over collective bargaining indicator in terms of influence over the wage determination process, as was done by Dabscheck (1977, p.399), the low score assigned to the ACTU by Wooden (1985, p.25) must be increased even before accounting for the influence of the social contract. Moreover, Wooden, like Headey, fails to assign weights to the various indicators and it reasonably could be argued that influence over wage determination overshadows all others in its importance.

Moving to a consideration of net benefits, union endorsement of the Accord at a Special Unions Conference in February 1983 was clearly influenced by the fact that it committed a Labour government to support a centralised wage-fixing system based upon full indexation. As in 1975, in the prevailing severely depressed economic conditions, a centralised system offered the prospect of more certain and more uniform wage increases than could be obtained otherwise. Also important in the near-unanimous union endorsement of the Accord was a desire to assist in the defeat of the Liberal-National Country Party (L-NCP) government, rather than support for its specific contents (Burgmann 1984, p.91). Likewise, acceptance of substantial modifications to the wages provisions at Special Unions Conferences, in 1985 and 1987, was influenced by concern regarding the laissez-faire policies if an L-NCP government was elected (Davis 1985, pp.595-6).

The position of the Amalgamated Metal Workers Union (AMWU) is of particular importance in securing union endorsement of the Accord and for its continuing viability. Over the period 1974-83, there were massive job losses in manufacturing, and this accelerated dramatically after the conclusion of the Metal Industry Agreement; for example, in the metals and engineering industries net losses amounted to 152,000 jobs (Stilwell 1986, p.97). Equally, the negotiation of the metal industry agreement underscored the AMWU's strategic significance and that its support was necessary in any successful social contract (Ewer, Higgins and Stevens 1987, p.98). Beginning in 1982, the AMWU response to the malaise in manufacturing was to substitute its longstanding strategy of shop-floor militancy and decentralised over-award bargaining with advocacy of a Swedishstyle social contract with the Labour Party (Stilwell 1986, pp. 27, 96-7). A manifestation of the AMWU's significance was the incorporation of industry policy into the final draft of the Accord (Ewer, Higgins and Stevens 1987, pp.98-9). By 'industry policy' it was meant that the government would adopt interventionist policies to establish a diversified and internationally competitive manufacturing sector. In view of the AMWU's size (with 120,000 members it is the largest manufacturing union and one of 
only ten unions with more than 80,000 members) and its history of opposition to cooption by the state, this change would have been important directly in eliminating a major source of destabilisation and providing an exemplar for union compliance.

Various more tangible benefits were foreshadowed in the Accord and, in the first eighteen months of the Labour government, wage restraint was rewarded with substantial gains across a range of areas. The major initiatives were tax reductions for low and middle income earners; increased expenditure and honouring of specific commitments on education, equal employment opportunity, job creation, health, housing, industry development, occupational health and safety and social security; extensive consultation through the establishment of the Economic Planning and Advisory Council, Advisory Committee on Prices and Incomes, the Australian Manufacturing Council and its sectoral constituents; and the establishment of the Prices Surveillance Authority. Rimmer (1987, pp.113-4) particularly emphasises the importance of the Prices Surveillance Authority, the extension of controls over non-wage incomes and the extensive network of consultative mechanisms. Unions as organisations benefited directly by legislative amendments facilitating union mergers, simplifying of financial accounting and reporting requirements and abolition of the Industrial Relations Bureau (ACTU 1984, Advisory Committee on Prices and Incomes 1984 and Stilwell 1986). The symbolic significance of the latter measure was considerable, because most unions regarded the Industrial Relations Bureau as the centrepiece of the conservative government's assault on unions.

Although the incentives for compliance are important, the capacity for enforcement is fundamental to Australian incomes policies. The focus in the ensuing paragraphs is on the ACTU's capacity for securing compliance, recognising the historically fragmented nature of Australian unionism. Specific changes considered are the ACTU's increased financial resources, reduced factional tensions, greater inclusiveness, growing recognition by the Commission of the ACTU's role in dispute settlement and wage determination and current pervasive political links. Taken together, factors both internal and external to the ACTU have combined to vest it with an unprecedented authority, albeit informal.

Regarding financial resources, the 62 cents per member affiliation fee collected by the ACTU in 1982 has been compared unfavourably with the 1.5 percent of gross wages collected by its Austrian equivalent and the low level of affiliation fees approved at Congress has been attributed to factionalism (Wooden 1985, pp.20-1). Placing this in the context of incomes policy, Wooden $(1985$, p.20) asserts that lack of resources "operates as a major restraint on the ability of the ACTU to both sell to its affiliates the need to cooperate" and to monitor the extent of their compliance. A similar point has been made also by Dabscheck (1983, p.404), that the ACTU officials have "been starved of funds and personnel, and as a result, have lacked the wherewithal if they ever had the desire to dominate affiliates".

While acknowledging the comparative resource deficiencies of the ACTU, Wooden does not consider the ends to which resources are directed and overlooks that, in recent years, there has been a significant and sustained increase in resources available to the ACTU. The latter change can be traced back to the 1979 Congress at which a crossfactional agreement resulted in the defeat of a proposal to lift affiliation fees from 25 cents per adult member to 75 cents, with a figure of 40 cents being agreed. In February 1980, a further compromise saw this increase to 60 cents. Congress agreed to raise affiliation fees to 80 cents in 1983 and further real increases, in 1985 and 1987, were not contested. Increased funding has been paralleled in ACTU staff levels, from 15 positions in 1981 to 41 in 1983 and 46 in 1985. As an index of the improvement in the ACTU's ability to communicate with affiliates and monitor their activities these increases were significant.

The increase in resources identified above is a major consequence of the lessening of factional tensions. In turn, this has increased the ACTU's credibility in the political and industrial arenas and has enhanced its perceived authority in dealing with affiliates also. Given that at least 79 percent of union members belong to the 162 unions affiliated to the ACTU, and that these include all 33 unions with more than 30,000 members (ACTU 
1987 , p.11), almost any union which attempts to contravene the incomes policy effectively can be isolated from fraternal support. Further, while Wooden (1985, p.20) concedes that only a few key affiliates, like the now-deregistered Builders Labourers Federation (BLF), have sufficient bargaining power to be immune to this sanction, their non-compliance and consequential widespread wages flow-ons are regarded as inevitable. As will be seen below, the predicted scenario did not unfold.

Evidence of greater unity of purpose is found in the conduct of the recent biennial Congresses and Special Unions Conferences and in the elections for the Executive. This has been most marked since the election of the Labour government in 1983; at the 1985 Congress, for example, the wages policy motion endorsing the Accord was moved on a cross-factional basis. More significantly, many resolutions were passed unanimously and a vote count was not required on any issue, a phenomenon not witnessed since 1939 (Martin 1985, p.102). Similarly, in the Executive elections, in 1985, a ballot was not required for 15 of the 18 industry group positions on the expanded Executive, and for the 3 vice-presidential positions a ballot was held only to determine which of the candidates would become senior vice-president. The diminution of factional tensions was aided by increasing the size of the Executive by 5 , to 31 , as was evidenced in the associated restructure of the industry group positions when, unprecedentedly, no affiliate opposed the proposed composition. Consequently, the Executive became large enough to provide a seat for most major ACTU affiliates and, as with its predecessor, the political factions had approximately equal representation. This tends to vest Executive decisions with an authority which is formally absent in the ACTU Constitution in which the only sanction is disaffiliation.

Also important is the ACTU's increased inclusiveness, a development facilitated by the transition from the 30-year incumbency of ACTU President Albert Monk to a younger generation of leaders notable for their pragmatism and dynamism. The first of this generation of professionals was Bob Hawke (now Prime Minister) who was elected President in 1969. The hallmark of the Hawke presidency was to place the ACTU on the consensus-seeking path (Rawson 1982, p.116) which characterises its present leadership. This is reflected in the conduct of Congress and the composition of the Executive discussed above.

The ACTU's inclusiveness is manifest both in the proportion of unionists belonging to affiliates and in their changed occupational composition. Hence, in 1961, the ACTU covered only 65 percent of unionists whereas present estimates range between 79 and 90 percent (ACTU 1987, p.11, Davis 1985, p.595). Much of this growth has been recent and has filled the major gaps in its occupational coverage, particularly among white-collar employees, which Martin (1968, p.150) had previously noted. Especially important were the mergers of rival confederations with the ACTU. The Australian Council of Salaried and Professional Associations (ACSPA), which covered some 163,000 unionists, merged in 1979. This was followed by the 132,000-member Council of Australian Government Employee Organisations (CAGEO) in 1981 and by the 95,000 -member Australian Public Service Federation in 1985. The significance of this is qualified, as a number of the ASCPA unions were dual affiliates and some major white collar unions, notably the Association of Drafting, Surveying and Technical Employees had switched their allegiances to the ACTU rather than await the merger (Griffin and Giuca, 1986, p.487). The end result of this process is that few influential unions remain outside the ACTU and it stands unrivalled by any equivalent organisation of employers. This vests it with considerable authority in dealing with individual affiliates, as censure by the ACTU potentially entails losing the moral and material support of all but the smallest unions. Indeed, the recent unsuccessful attempts by the Plumbers and Gasfitters Employees Union (PGEU) to circumvent the wage-fixing principles and resist employer invocation of various legal sanctions suggests that the term collective solidarity has acquired a new meaning. 
Central to the ACTU's metamorphosis is its symbiotic relationship with the Commission, and this is evidenced in the latter's occasional departures from a strict interpretation of the wage-fixing principles largely to meet the needs of the ACTU. On one occasion, the Commission allowed an over-award claim to be processed as an anomaly (ACAC 1984a, pp.16-18), and on another, it varied the principles outside of the scheduled review (ACAC 1985b, pp.15-16). The Commission's growing recognition of the strategic significance of the ACTU stems partly from its influence over affiliates and operates to reinforce that influence. The substantial bases of this influence are the ACTU's frequent intervention in disputes with a high public profile or adverse consequences for other affiliates, co-ordination of award negotiations in key areas, such as the oil industry, and conduct of national test cases, particularly in relation to wages and shorter working hours.

The ACTU has a history of involvement in industrial disputes and this has sometimes been decisive. In the immediate post-war period, its interventions in disputes involving the militant left-wing Seamen's Union of Australia, Miners Federation and the Waterside Workers Federation (Hagan 1981, pp.232-44 and Martin 1968, pp.153-4) were especially notable. This is buttressed by the fact that, since its inception, the ACTU has been the principal union representative in the basic wage and margins cases (pre-1967) and the national wage cases (post-1967) in which the Commission has articulated wages policy. Only occasionally have unions been represented separately, other than by ACSPA or CAGEO. It also has been argued (Plowman 1983, p.415) that the ACTU's pivotal role has been assured by the Commission's experiences in the $1960 \mathrm{~s}$, specifically, the growth of over-award bargaining and the abandonment of penal sanctions after a union campaign of opposition. For the first time, there was a very real threat that large numbers of unions would desert the arbitral system in favour of direct bargaining and the Commission's authority in industrial relations was severely diminished by the political realities of enforcement. Rimmer (1987, p.89) has emphasised also the influence of "eccentric wage decisions" by the Commission in the post-war period and the increased "independent strength of employers and unions".

Finally, the importance of political links cannot be overestimated; their effective use demonstrates the value of ACTU affiliation to pragmatic and politically uncommitted unionists. Without them, arguably, the ACTU would have been much less successful in securing the affiliation of white collar unions (Rawson 1978, p.77).

The ACTU's formal links with the Labour Party are of quite recent origin (Martin 1968, p.150). As there had been no federal Labour government during most of the postwar period, the ACTU relied on strong but informal links, such as the overlap and exchange of personnel with the Labour Party. Surprisingly, this did not change when Labour held office in the period 1972-75; informal links, like Hawke's presidency of both the Labour Party and ACTU and Labour Minister Cameron's many contacts in unions, were utilised almost exclusively (Rawson 1982, p.111). By contrast, during the ensuing conservative government, 1975-83, a programme of legislation aimed at impeding union functioning (see Mitchell 1978 and MacCallum 1980 especially) and repeated attempts to reduce the value of various components of the social wage propelled the ACTU into a leadership role in which formal links played a decisive role. Rawson (1982, p.113) argues this was a major source of the ACTU's growth over the period 1975-83, during which the ACTU gained most of the major white-collar affiliates.

The election of a Labour Government in 1983 brought extensive use of both types of links. It is doubtless significant that the Prime Minister was previously the ACTU President and the Minister for Industrial Relations, Ralph Willis, had been its Industrial Advocate and that relations between the leaders were cemented during the prolonged negotiation of the Accord. More concretely, a range of consultative structures was established pursuant to the Accord. The capacity of the ACTU to intervene on behalf of affiliates is recognised by unions and as such is a source of influence over them. 
Although Australia has a large number of sometimes competing unions, this does not necessarily preclude the operation of a viable incomes policy. Focusing on the nature of the ACTU and changes in its character, by 1983 the ACTU was poised to play a strategic role in implementing the incomes policy. It would be naive to conclude that the ACTU's influence over affiliates will not wane over time; the failure to achieve a sustained economic recovery or, conversely, a rapid expansion of employment could shatter the fragile internal consensus among ACTU affiliates resulting ultimately in the demise of the incomes policy and the associated consultative structures. It would be equally naive to ascribe the ACTU's influence over affiliates solely to economic conditions. Nevertheless, if economic or political factors undermine the conditions for a continuing incomes policy, the experience of 1975-81 suggests the ACTU leaders will respond to the mood of its affiliates and withdraw their support.

\section{The ACTU and union compliance}

Apart from some inconclusive evidence of wages drift ${ }^{1}$, there is little to suggest that non-compliance was a problem during the first three years of the social contract. Alongside falling direct and indirect labour costs, the operation of the Accord was characterised by an exceptional decline in industrial disputation ${ }^{2}$, particularly over wages issues. It remains however to clarify the ACTU's role in this shift.

The role of the ACTU is not confined to enforcing the wage-fixing principles on recalcitrant unions; its influence with the federal government and the Commission is used also to obtain concessions which might not be available to unions operating in isolation. This combination of penalties and rewards has not always been effective; however, only a small number of unions have succeeded in circumventing the principles, and this has not led to widespread non-compliance, despite the existence of divergent interests within and between unions.

Along with the Builders Labourers Federation, the 11,000-member Food Preservers Union (FPU) was one of few unions which repeatedly challenged the incomes policy. The three best known disputes involved the imposition of work bans on the H.J. Heinz Company, Plumrose (Australia) Limited and Rosella-Lipton Proprietary Limited.

The Heinz dispute was particularly hard-fought, lasting eleven weeks and involving stand-downs of employees who refused to work "as directed", and eventually the wage demands were conceded. During the dispute, the Commission repeatedly sought ACTU intervention to have the bans lifted. The ACTU's failure was reflected in part in the pessimistic note sounded by the Commission in its decision introducing the centralised system:

Notwithstanding the commitment given by the ACTU for the future we express our great concern at the industrial actions proceeding currently to obtain sectional claims... which may unsettle relativities and generate flowons inconsistent with the principles about to come into operation (ACAC 1983, p.18).

The Heinz dispute was followed closely by a dispute with Nestles over its refusal to grant claims, including a flow-on of the 4.3 percent national wage decision and a 16 dollar catch-up. There the ACTU achieved a settlement, persuading the union to drop the catchup claim and accept a working party examination of rosters (Workforce 1983b, p.1). Statistics (ABS) 1985a 
In September 1984, the FPU finally undertook to abide by the principles. The timing is consistent with the union recognising that the negative CPI figure in the first two quarters of 1984 precluded the prospect of further wage rise before an expected national wage decision in March 1985 (see table 1). A commitment to the principles, however, ensured FPU members a flow-on of the 4.1 percent awarded in April 1984. Also important in this changed attitude were clear indications that the union had little support from the ACTU or other affiliates. This was not the end of FPU challenges to the principles, but it appears that subsequent disputes lacked official union backing and did not represent a deliberate challenge to the principles.

The Builders Labourers Federation is almost certainly the only union which, having undertaken to abide by the principles, proceeded systematically and repeatedly to breach them. The BLF's conduct eventually resulted in an extraordinary scenario in view of Labour's past opposition to the use of penalties in industrial relations. The federal government enacted special legislation which, via an extensive inquiry undertaken by the Commission, led to its deregistration pursuant to the legislation. Complementary action was taken by the governments of New South Wales and Victoria in relation to the BLF's state-registered counterparts. Further federal legislation resulted in its membership being allocated to other unions in the industry and, with the tacit consent of the ACTU, they willingly recruited the former BLF members.

In early 1983, the ACTU and the government intervened successfully to halt disputation occurring in relation to negotiations over a building industry agreement. The outcome was a moratorium on industrial action over the union claims, the commencement of detailed negotiations under the auspices of the ACTU and federal government agreement to withdraw from deregistration proceedings against the BLF which were initiated by its predecessor. In the subsequent Federal Court proceedings, the government relied heavily on an ACTU Executive resolution that it would take all reasonable steps to secure the union's compliance with its undertakings to adhere to the terms of the Conciliation and Arbitration Act (ACAC 1984b, pp.22-4). In itself, this was a potent demonstration of the ACTU's influence and could be expected to have reinforced its control over affiliates.

However, during 1983 and 1984, the BLF rejected any lasting commitment to the principles. Despite the best efforts of the ACTU, undertakings by the BLF were repeatedly broken by industrial action which at one stage jeopardised the national wage indexation adjustment. The Commission found that the BLF had deliberately and repeatedly breached the principles, but rather than penalise all unions parties to the award, it did not withhold the indexation adjustment. In its decision, the Commission clearly attests the importance of the ACTU:

\begin{abstract}
We place particular stress on the role of the ACTU. That body has played a responsible part in co-ordinating the negotiations and is endeavouring to eliminate industrial action associated with the superannuation claim (ACAC 1984b, p.17).
\end{abstract}

During the course of 1985 , the ACTU made numerous well-publicised but unsuccessful attempts to have the BLF adhere to its various undertakings, including that to adhere to the principles. By August, with the federal government seemingly committed to pursuing the BLF's deregistration, the ACTU abandoned its efforts to influence the union's conduct or to dissuade the government from its chosen course. This was the only significant case in which the ACTU failed, however, the absence of union and ACTU support for the BLF was a significant departure from the union movement's traditional implacable opposition to the use of deregistration. Implicitly, this serves to demonstrate to other unions the dangers of falling foul of the ACTU.

Other unions breached the principles, but more sporadically. In those instances, ACTU influence was often strategic, either in securing union compliance or by isolating the miscreant from vital fraternal support. In the case of the Federated Furnishing Trades 
Society (FFTS), a three-week strike yielded a "disability" allowance for two hundred members employed by an aluminium window manufacturer. This settlement, with potential for uncontrolled flow-ons throughout the metal and building industries, received widespread publicity with both the ACTU and the government combining to denounce the union. Following meetings with the ACTU, the allowance was withdrawn and the employees paid for lost time.

Widespread and severe industrial action followed the Commission's rejection of an 8.3 percent wage claim which public sector unions had argued under the anomalies principle. ACTU intervention brought the resumption of negotiations between unions and government and an unprecedented submission to the national wage case seeking to have the revised claim referred to the Anomalies Conference. In the ensuing proceedings, ACTU involvement was crucial to the decision granting modest wage increases. The Commission quoted extensively from the ACTU submission and stressed its reliance on ACTU undertakings to oppose affiliates advancing similar claims, unless they met stringent tests in terms of merit and containment of flow-on (ACAC 1985c, p.12). Without ACTU involvement, the Commission could not have exhibited flexibility in reviewing its previous decision, except at the expense of its own credibility and the viability of the principles.

A distinguishing feature of the cases considered above is that, while the important role of the ACTU was acknowledged by other actors, there is little direct evidence of the ACTU exhorting unions to comply with the principles. Revisions of the positions adopted by recalcitrant unions is testimony that, in private, the union confederation was actively enforcing the principles. It is relevant also that, since 1983, the ACTU position on wages and other issues related to the Accord has invariably reflected a consensus of the views of the major unions. Consequently, there was little need for public division or exhortation. There were, of course, exhortations in the context of the ACTU Congress, but mostly these were designed to convince affiliates of the benefits of the social contract. Thus, the President's addresses to the Congress in 1983 and 1985 stressed the long term benefits of the Accord, listed concessions already gained and warned that, without the Accord, the existence of a Labour government would be jeopardised. In 1983, however, two senior Executive members made forceful criticisms of the renegade FPU. As Laurie Carmichael, then also a senior AMWU official scathingly observed:

Those who have got the idea that the road to socialism is by an individual wage struggle in half a dozen factories without mobilising all of the workers,..., have no bloody idea whatever what it's about (Davis 1983, p.513).

At the 1985 Congress, the emphasis of the wages resolution was on the choice between the market and a centralised wage-fixing system allied with the solid benefits arising from the Accord (Martin 1985, p.104).

\section{After the Accord Mark 1}

The wages provisions of the social contract have twice undergone major revisions and on both occasions the direction has been similar. Quite simply, the effects of Labour's deregulation of the exchange rate and capital movements and the appeal of further economic deregulation among senior ministers ensured that the Accord commitment to real wage maintenance was jettisoned and that a more decentralised wage-fixing system was devised.

The first shift occurred pursuant to the scheduled re-negotiation of the wages provisions of the Accord and endorsement of those changes by the ACTU Congress, in September 1985. The major feature of the Accord Mark 2, as it became known, was the 
union movement's unprecedented acceptance of partial wage indexation. On this occasion, a discount of up to two percent was accepted by Congress in recognition of the effects of the rapid devaluation of the exchange rate and to preserve Australia's improved international competitiveness. In exchange, the government was committed, among other things, to an equivalent reduction in personal income tax, supporting full indexation in the current national wage case, encouraging the extension of industry and occupation-based superannuation and supporting an ACTU claim for a 3 percent productivity-based wage claim to be paid in the form of increased superannuation. Significantly, there was only isolated opposition to this package on the floor of Congress and the resolution was adopted unanimously.

The Accord Mark 2 was not fully considered by the Commission until early 1986 and its decision was incorporated into the principles in June 1986. On the issue of discounting, the Commission arrived at the same figure previously agreed to by the ACTU and the government (ACAC 1986b, p.16). Regarding the inter-related issues of productivity and superannuation, the Commission's decision is best described as artful; it rejected the productivity claim because of its potential adverse effects on profitability, but, in view of the widespread incidence of agreements and negotiations on superannuation and expectations generated by the Accord Mark 2, it did not rule on superannuation. Instead, the Commission attempted to contain labour costs by introducing a principle expressing its intention to regulate the order and timing with which agreements were implemented and setting an upper limit of a 3 percent wage equivalent increase. There followed a campaign orchestrated by the ACTU in which strategically placed affiliates pushed for new or improved superannuation benefits.

The ink was hardly dry on the June national wage decision when employers and the government began publicly to press for a more flexible wage-fixing system, one which would deliver real wage reductions in the short term (Petridis 1987, pp.76-83). By December, this campaign resulted in the Commission formally terminating wage indexation and adumbrating new principles on which there was an unusual degree of unanimity between the ACTU, employers and the government. The Commission justified its decision as a response to the continuing and severe deterioration in economic conditions, especially the terms of trade and the current account deficit, and the pessimistic outlook. Its assessment of the parlous state of the economy was encapsulated in the statement that: "While the direct effect of wage increases on the CPI may have been small,...it is the highest rate since June 1983" (ACAC 1987, pp.5-6).

Not only did the ACTU accept this assessment of the economy and the importance of containing wages growth, it proposed new wage-fixing guidelines, effectively relinquishing its longstanding pursuit of wage indexation. Thus, a Special Unions Conference, in November 1986, endorsed an ambit claim for full wage indexation, but with a fall-back position seeking a two-tier system providing for two flat increases in the first tier and scope for negotiated or arbitrated increases in the second (ACTU 1986). This position was shared substantially by the government and the Confederation of Australian Industry, the major employer organisation. The ACTU justified its pragmatism as working towards a "centralised wages system that has the potential to sustain living standards of all workers, particularly low and middle income earners" (ACTU 1986). Hence, it could be argued that the two-tier system was derived from the concept of a needsdetermined basic wage which the ACTU had pursued from its inception, in 1927, until the early 1960s. Consistent with this and the thrust of the Accord, the resolution also stressed the need for the government to "provide for needs through substantially increased family allowances". This gained concrete expression in a wage-fixing principle providing for granting and adjusting supplementary payments in minimum rates awards, subject to the second tier ceiling.

The basis of the wage-fixing principles introduced in March 1987, was to provide for flexibility within centrally determined limits: there would be "determination in a National Wage Case of a maximum level of increase that can be sustained over a period of time 
having regard to the broad range of industrial, economic and social factors affecting Australian society" (ACAC 1987, p.8). The cornerstone concepts of collective and individual commitment were retained. The first tier ceiling was set at 1.5 percent over the ensuing year and this was to be awarded in two stages: it began with a flat increase of 10 dollars and, following a prolonged review, a further 6 dollars was awarded in February 1988. The second tier ceiling was set at 4 percent of wages and this was applied to most of the existing categories of exceptional increases.

The most radical feature of the two-tier system, and it was here that the union movement's cohesion was tested, was in providing for wage increases on the basis of specified improvements in efficiency achieved by job restructuring and eliminating inefficient management and work practices. Inclusion of the restructuring and efficiency principle was designed to encourage plant and enterprise negotiations within the context of framework industry agreements. Agreements were to be subject to ratification by the Commission and it would arbitrate if negotiations failed, but in those cases the introduction of increases was to be deferred. Fundamentally, this was a tripartite initiative to entrench collective bargaining within a centralised wage-fixing system and thereby to accommodate the ascendant deregulatory sentiments. That such a move was palatable to the ACTU and the vast majority of its affiliates has to be seen in the context of the scope in the second tier for wage rises for both lower-paid and strategically located workers and the extraordinary economic and political climate. With a federal election scheduled during 1987 , the viability of the wage-fixing system was critical to the retention of a Labour Party government.

Labour was re-elected in July and yet, by the end of 1987, the second tier had not declined into a generalised wage round; few agreements were ratified before July and it has been estimated that only 20 percent of employees had obtained increases by December (Age 1987, p.12). As to the authenticity of the concessions, some have been predictably trivial but others have been quite major; for example, shortening or eliminating the Christmas shutdown, staggered breaks to ensure work continuity, greater flexibility in taking rostered days off, multi-skilling, reduced demarcations, rationalisation of job classification structures, introduction of twelve-hour shifts and reducing the application of penalty payments.

The significance of the developments discussed above is that the ACTU jettisoned full wage indexation, ostensibly in the short-term, and agreed to uphold its replacement for a twelve-month period. Remarkably, with the exception of the Plumbers and Gasfitters Employees Union, most unions accepted the evolving wage-fixing arrangements, despite substantial falls in real wages beginning in 1986. The pay-off for the ACTU and its affiliates was preservation of the living standards of the low paid, directly through the wage-fixing system and indirectly through the social wage, and scope for increases for strategically placed groups of workers, particularly in manufacturing.

Other than the PGEU, the ACTU seems to have been able to contain challenges to the wage-fixing system. Their challenge began with a refusal to make a commitment to the revised principles, introduced in June 1986, and was followed with a national industrial campaign over a log of claims which included a demand for a wage increase of 70 dollars per week to compensate for income losses caused by departures from full indexation since 1983. The continued application of bans against major building projects and the union's refusal to adhere to ACTU policy saw employers pursue a range of legal sanctions beginning with the insertion of penal clauses in the union's award and culminating in the imposition of fines totalling 280,000 dollars pursuant to the provisions of section 45D of the Trade Practices Act. Finally, in December 1987, with a second tier wage increase being paid to all other building workers and agreement for a severance pay scheme concluded, the PGEU conceded defeat citing the debilitating effects of legal sanctions (Australian Financial Review 1987, p.3). Doubtless, the apparent capacity of the other unions and the ACTU to gain a concession with limited flow-on potential was significant too. 
Having made the transition away from wage indexation, there remains the question of whether the ACTU can ensure continued union compliance with the centralised wagefixing system.

\section{Discussion}

Although the Commission is generally well-suited to the conduct of an incomes policy, it is deficient in several ways. Because of this, a mechanism was needed to deliver union compliance. The ACTU was such a mechanism, however, its co-operation and capacity for enforcement cannot be assumed to be absolute and unchanging.

A major institutional feature facilitating an effective incomes policy is the network of federal and state tribunals which, through a combination of law and convention, can provide centralised regulation of wages and conditions of employment. Against this are several considerations, especially the Commission's inability to compel state tribunals to follow its wage-fixing principles and the fact that since the 1960 s the Commission has lacked effective sanctions with which to enforce its decisions. It is this latter consideration in particular which has been regarded as a major obstacle to the operation of an incomes policy.

The corollary of lack of effective sanctions has been a view of Australian unions as individually powerful organisations able to extract favourable wages settlements from employers. This view is flawed in two key respects. It takes insufficient account of the institutional dependence of Australian unions on the conciliation and arbitration systems from which they derive their registration and the associated benefits. Although some unions, such as the Amalgamated Metal Workers Union and the Coal Miners Federation, have a longstanding record of militancy usually deriving from strong shop-floor organisation, the majority have been either reluctant or unable to challenge tribunal decisions, except in propitious economic circumstances.

Allied with this, the role of the ACTU in shaping or constraining these wages campaigns is frequently misunderstood. In effect, the reciprocal of the organisational weakness of unions is their susceptibility to co-ordination and even control by the ACTU. This is not to suggest that the ACTU's degree of formal control over affiliates is equivalent to that enjoyed by some of its European counterparts. Control over affiliates should not be measured solely in terms of formal powers and organisational structure. It is also important to assess the extent to which the influence of a union confederation is enhanced by the role which it is given by other institutions and by union affiliates.

Of particular interest was the adoption of the Accord and the subsequent introduction of a modified wage indexation system in 1983. This marked a departure from all previous periods of centralised wage-fixing, including the case by case approach adopted by the Commission in 1981 and the wages pause of 1982 . This was the first occasion on which the ACTU embraced a centralised system to the point of accepting a role in the suppression of over-award bargaining. In the absence of a pervasive economic crisis and without the wide-ranging provisions of the Accord, it is unlikely that this change would have occurred.

In the case of the Accord-based incomes policy, the Commission has assigned the ACTU a pivotal function in ensuring the compliance of individual affiliates and has reinforced this by a willingness to give an especially favourable reception to arguments advanced on their behalf by the ACTU. The importance assigned to the ACTU is further reinforced by its apparent influence on the federal government as evidenced, for example, by its ability to obtain concessions on behalf of the renegade Builders Labourers Federation. Thus, until recently, the logic of incomes policy has turned on substituting legal sanctions for the subtler pressure able to be exerted on individual unions by an ACTU with significant influence at high levels in the state apparatus. Recent developments involving the PGEU, but also other unions, indicate that economic 
conditions and the fear of a conservative government may have assigned legal sanctions a secondary role in securing union compliance.

At least equally important to the viability of centralised wage-fixing, and the incomes policy of which it is a major part, is unions' willingness to cede even partial control over target wage levels and structures to the ACTU. In this relation, it is striking that the traditionally militant Amalgamated Metal Workers has been a cornerstone of union support for the Accord and that this has carried over through successive re-negotiations of its wages provisions and the Commission's revisions of the principles. Thus, at least in the short term, Australian unions have foregone their historical attachment to the goal of real wage maintenance and obtained in exchange some relief for low-wage earners and limited scope for decentralised collective negotiations within the context of an incomes policy.

It remains to be seen whether the Australian incomes policy is viable over the long term, that is, when the sense of economic crisis which has pervaded the operation of the wage-fixing principles has passed. What is reasonably clear is that the combination of a union confederation having strong influence on a social democrat government and industrial tribunals capable of centrally fixing wages can ameliorate disputation and lower the rate of wages increase over the short to medium term. This model could readily be applied across the Tasman, but so far the prospect of a social contract seems to have found little favour with either the Lange government or the unions.

Ironically, present indications are that the Australian system may develop toward its New Zealand counterpart. It has become evident that the termination of indexation adjustments was not intended to be temporary as originally suggested by the ACTU. Rather, this was an interim stage in developing a more market oriented wage-fixing system, one designed to facilitate structural adjustments as well as combat inflation. Under such a regime it can be expected that individual unions will have an enhanced role in wage-fixing, possibly at the expense of the ACTU.

\section{References}

Advisory Committee on Prices and Incomes (1984) Prices and incomes policy, the third progress report on government initiatives, December, Canberra, AGPS.

Australian Bureau of Statistics (1985a) Employee benefits Australia, Catalogue No. 6334.0 .

Australian Bureau of Statistics (1985b) Industrial disputes Australia, Catalogue No. 6322.0 .

Australian Conciliation and Arbitration: Commission (1983) National wage case, March and June quarters 1983, Decision, 23 September, Print F2900.

Australian Conciliation and Arbitration Commission (1984a) National wage case, September and December quarters 1983, Decision, 4 April, Print F500.

Australian Conciliation and Arbitration Commission (1984b) Applications to vary the National Building Trades Construction Award 1975 and others, Decision, 13 June, Print F5763.

Australian Conciliation and Arbitration Commission (1985a) National wage case, September and December quarters 1984, Transcript, C. Nos. 128-158 and others. 
Australian Conciliation and Arbitration Commission (1985b) National wage case, September and December quarters 1984, Decision, 3 April, Print F8100.

Australian Conciliation and Arbitration Commission (1985c) Applications by the Administrative and Clerical Officers Association, Australian Government Employment and others to vary various determinations and awards, Decision, 24 May, Print F8642.

Australian Conciliation and Arbitration Commission (1986a) Application by the Minister for Employment and Industrial Relations in relation to the Australian Building and Construction Employees and Builders Labourers Federation, Decision, 4 April, Print G2792.

Australian Conciliation and Arbitration Commission (1986b) National wage case Decision, 23 December, Print G6400.

Australian Conciliation and Arbitration Commission (1987) National wage case Decision, 11 March, Print G6800.

Australian Council of Trade Unions (1984) The Implementation of the accord: an ACTU review, mimeographed, October.

Australian Council of Trade Unions (1986) ACTU wages resolution of special unions conference, 6 November.

Australian Council of Trade Unions (1987) Strategies for the future, mimeographed, May.

Australian Financial Review (1987) PGEU deal with NSW employers, 4 December: 3.

Australian Government (1985) Commonwealth submission to the national wage case, September 1985, Exhibit Commonwealth 11.

Australian Government, Department of the Treasury (1985) The round-up, Canberra, Australian Government Publishing Service.

Beggs, J J and Chapman, B J (1986) An empirical analysis of Australian strike activity: estimating the industrial relations effects of the prices and incomes accord Australian National University, Centre for Economic Policy, Discussion Paper No. 141, May.

Blandy, R and Creigh (1983) The Australian labour market June 1983 Australian bulletin of labour 9: 159-87.

Boston, J (1986) Is corporatism a viable model for New Zealand? paper delivered to a seminar at the Industrial Relations Centre, Victoria University, Wellington, New Zealand.

Burgmann, M (1984) Australian trade unionism in 1983 Journal of industrial relations 26 March: 91-8.

Business Council of Australia (1985/6) Survey of labour costs: 1983/84 and 1984/85 Business Council Bulletin No 19 December/January: 14-17.

Business Council of Australia (1987) Survey of labour costs: 1984-85 and 1985-86 Business Council Bulletin No. 30 January: 7-9. 
Cameron, D R (1984) Social democracy, corporatism, labour quiescence and the representation of economic interest in advanced capitalist society. In Goldthorpe, J H (ed) Order and conflict in contemporary capitalism, Oxford, Clarendon Press: 143-78.

Crouch, C (1982) The politics of industrial relation London, Fontana.

Dabscheck, B (1977) The internal authority of the ACTU Journal of industrial relations 19 December: $388-403$.

Dabscheck, B (1983) Unions and wage policy. In Ford, B and Plowman, D (eds) Australian unions: an industrial relations perspective South Melbourne, Macmillan: 40011.

Davis, E (1983) The 1983 congress: Congress Rules OK! Journal of industrial relations 25 December:507-16.

Davis, E (1985) The 1985 ACTU congress: consensus 2 Journal of industrial relations 27 December:592-603.

Davis, E (1986) On Furstenburg and Noakes. In Blandy, R and Niland, J (eds) Alternatives to arbitration Sydney, Allen and Unwin: 235-40.

Dawkins, P and Blandy, R (1985) Labour costs and the future of the accord Australian economic review 2nd quarter:37-50.

Dunkley, G. (1984) Can Australia learn from Austria about incomes policies? Journal of industrial relations 26 September:365-84.

Fulcher, J (1987) Labour movement theory versus corporatism: social democracy in Sweden Sociology 21 May:231-52.

Ewer, P, Higgins, W and Stevens, A (1987) Unions and the Future of Australian Manufacturing Sydney, Allen and Unwin.

Goldthorpe, J H (ed) (1984) Order and conflict in contemporary capitalism, Oxford, Clarendon Press.

Griffin, G and Giuca, V (1986) One union peak council: the merger of ACSPA and CAGEO with the ACTU Journal of industrial relations 28:483-503.

Hagan, J (1981) The history of the ACTU Melbourne, Longman Cheshire.

Headey, B W (1970) Trade unions and national wages policies Journal of politics 32 May:407-39.

Higgins, W (1985) Political unionism and the corporatist thesis Economic and industrial democracy 6:349-81.

Hince, K (1985) Wage fixation in a period of change: the New Zealand case. In Sutcliffe, $\mathrm{P}$ and Ralston, D (eds) Trends in Australasian industrial relations (Proceedings of conference) Brisbane, Association of Industrial Relations Academics of Australia and New Zealand: 41-57. 
Isaac, J E (1984) Wage determination and economic policy. In Chapman, B J, Isaac, J E and Niland, J R (eds) Australian labour economics: readings Melbourne, Macmillan: 12843.

Kain, P, Kenyon, P and Wooden, M (1986) The Australian labour market in December 1986 Australian bulletin of labour 13 December:3-33.

Kenyon, P (1986) The Australian labour market June 1986 Australian bulletin of labour 12 June:131-53.

Lange, P (1984) Unions, workers and wage regulation: the rational bases of consent. In Goldthorpe, J H (ed) Order and conflict in contemporary capitalism Oxford, Clarendon Press: 98-123.

Lehmbruch, G (1984) Concertation and the structure of corporatist networks. In Goldthorpe, J H (ed) Order and conflict in contemporary capitalism Oxford, Clarendon Press: 60-80.

MacCallum, R (1980) Secret ballots and the industrial relations bureau: old wine in new bottles. In Ford, G.W et al (eds) Australian labour relations readings Melbourne, Macmillan: 368-94.

Martin, R M (1968) The authority of trade union centres: the Australian council of trade unions and the British trade union congress. In Isaac, J E and Ford, G W (eds) Australian labour relations readings Melbourne, Sun Books: 140-59.

Martin, R M (1985) The ACTU congress of 1985 Labour history No 49 November:10212.

Melbourne Age (1987) Australia's industrial relations revolution finally impinges on sacrosanct penalty rates 25 November: 12

Mitchell, R (1978) Industrial relations under a conservative government: the coalition's labour law programme, 1975-1978 Journal of industrial relations 41 December:435-65.

Muller-Jentsch, W (1985) Trade unions as intermediary organisations Economic and industrial democracy 6 February:3-34.

National Economic Summit Conference Communique (1983) April, Australian Government.

New Zealand Government (1985) Green Paper, Industrial Relations A Framework for Review Vol. 2 Wellington, Government Printer.

Nieuwenhuysen, J (1986) In flexibility and strength: tribunals and the wage fixation process. In Niland, J (ed) Wage indexation in Australia Sydney, Allen and Unwin:66-83.

Olson, M (1982) The rise and decline of nations New Haven, Yale University Press.

Petridis, A (1987) Wage policy and wage determination in 1987 Journal of industrial relations 29 March:75-83. 
Phelps Brown, E H (1977) A social contract for Australia?. In Nieuwenhuysen, J P and Drake, P J (eds) Australian economic policy Melbourne, Melbourne University Press: 7383.

Plowman, D (1983) Unions and incomes policy. In Ford, B and Plowman, D (eds) Australian unions: an industrial relations perspective South Melbourne, Macmillan: 412 34.

Plowman, D (1984) Full circle: Australian wage determination 1982-1984 New Zealand journal of industrial relations No 95:95-112.

Rawson, D W (1978) Unions and unionists in Australia Sydney, Allen and Unwin.

Rawson, D W (1982) The ACTU - growth yes, power no. In Cole, K (ed) Power, conflict and control in Australian trade unions Ringwood, Penguin:102-20.

Regini, M (1984) The conditions for political exchange: how concertation emerged and collapsed in Italy and Great Britain. In Goldthorpe, J.H (ed) Order and conflict in contemporary capitalism Oxford, Clarendon Press: 124-42.

Rimmer, M (1987) Australia: old wine in new bottles. In Bilson, B (ed) Wage restraint and the control of inflation London, Croom Helm: 78-120.

Schott, K (1984) Policy, power and order: the persistence of economic problems in capitalist states London and New Haven, Yale University Press.

Schott, K (1985) The consensus economy: an international overview Economic papers 4 June:1-22.

Scharpf, F W (1984) Economic and institutional constraints of full-employment strategies: Sweden, Austria, and West Germany, 1973-1982. In Goldthorpe, J.H (ed) Order and conflict in contemporary capitalism Oxford, Clarendon Press: 257-90.

Statement of accord by the Australian labour party and the Australian council of trade unions regarding economic policy (1983).

Stilwell, F (1986) The accord...and beyond Sydney and London, Pluto Press.

Streek, W (1984) Neo-corporatist industrial relations and the economic crisis in West Germany. In Goldthorpe, J.H (ed) Order and conflict in contemporary capitalism Oxford, Clarendon Press: 291-314.

Teicher (1987) Unions, the ACTU and Australian wages policy Management Paper No. 7 Graduate School of Management, Monash University, June.

Wooden, M (1985) Achieving consensus in a pluralist society Journal of Australian political economy No 19 December: 14-28.

Workforce (1983a) Food preservers union: neither government nor ACTU can do much 26 October: 6.

Workforce (1983b) ACTU's Bill Kelty settles Nestles dispute 10 November: 1.

Workforce (1985) BLF 36-hour campaign again defers 2-6\% flow-on 22 May: 16. 
Wright, M and Apple, N (1980) Incomes policy and industrial relations: Britain, Sweden and Australia Journal of industrial relations 22 December: 453-75.

Yerbury, D (1980) Collective negotiations, wage indexation and the return to arbitration: some constitutional and legal developments during the Whitlam era. In Ford, G.W et al (eds) Australian labour relations: readings Melboume, Macmillan: 462-503. 